\title{
The Effect of Copper on Red Cell Enzyme Activities
}

\author{
M. Boulard, K.-G. Blume, and E. Beutler \\ From the Department of Hematology, City of Hope Medical Center, \\ Duarte, California 91010
}

\begin{abstract}
A B S T R A C T Previous studies have shown a marked effect of very high levels of copper on red cell glucose6-phosphate dehydrogenase and glutathione. When the effect of more nearly physiological levels of copper were studied, red cell hexokinase, phosphofructokinase, phosphoglyceric kinase, pyruvate kinase, and 6-phosphogluconate dehydrogenase were found to be inhibited. Inhibition was observed both when copper was added directly to hemolysates or when hemolysates were prepared from red cells from whole blood which had been incubated with copper and washed. The inhibition of red cell enzymes by copper was completely reversed by the addition of EDTA.
\end{abstract}

\section{INTRODUCTION}

In some patients with Wilson's disease periodic increases in circulating, nonceruloplasmin-bound, copper occur. This results in features of acute copper intoxication, including hemolytic anemia (1). For this reason the hemolytic process induced by copper has been the subject of many recent studies (2-8). Interest has been focused primarily on glutathione and glucose-6-phosphate dehydrogenase (G-6-PD), ${ }^{1}$ which have been shown to be affected by high levels of copper (3-7). Since the levels of copper which have been shown to affect G-6-PD and glutathione are greatly in excess of the concentrations encountered in Wilson's disease, we have now studied the effect of much smaller increases in copper levels on red cell glycolytic enzymes.

\section{METHODS}

The effect of copper on red blood cell enzymes was studied in hemolysates and in whole blood. The final copper con-

Dr. Boulard's present address is Charge de recherches I. N. S. E. R. M., Laboratoire des isotopes, Hospital St. Louis, Paris $10^{\circ}$, France.

Receivcd for publication 7 October 1971 and in revised form 22 November 1971.

${ }^{1}$ Abbreviations used in this paper: G-6-PD, glucose-6phosphate dehydrogenase; GSH, reduced glutathione; HK, hexokinase; PFK, phosphofructokinase; 6-PGD, 6-phosphogluconate dehydrogenase; PGK, phosphoglyceric kinase; $\mathrm{PK}$, pyruvate kinase. centrations used in all the experiments were $15 \mu \mathrm{Mr}, 50 \mu \mathrm{M}$, and $100 \mu \mathrm{M}$. Copper sulfate was used as the source of $\mathrm{Cu}^{++}$, and the possible effect of the sulfate ion on the enzymes studied was controlled by using sodium sulfate at the same concentrations. Blood samples from normal donors were collected in acid citrate dextrose solution formula A (9). Enzyme assays were carried out in $1 \mathrm{ml}$ assay systems according to previously described methods (9), except that all hemolysates were prepared in water instead of the EDTA- $\beta$-mercaptoethanol-NADP-stabilizing solution.

In the first group of assays copper was added to the cuvettes containing the incomplete reaction mixture including the hemolysates. The reaction was started after the specified incubation period (9) by adding the substrate of the enzyme. Assays were also carried out with the addition of a final concentration $400 \mu \mathrm{M}$ EDTA before the reaction was started. Additional blanks with copper were assayed in order to correct for any change in the reaction mixture absorbance due to the presence of copper.

In experiments with intact cells, normal whole blood samples were incubated for $2 \mathrm{hr}$ at $37^{\circ} \mathrm{C}$ with copper sulfate at final concentrations of 15,50 , and $100 \mu \mathrm{M}$. The red blood cells were washed three times in cold $0.145 \mathrm{M} \mathrm{NaCl}$ solution and enzyme assays were performed on the water hemolysates. Assays were also carried out on hemolysates dialysed for $18 \mathrm{hr}$ against $80 \mu \mathrm{M} \mathrm{NaCl}$ or $20 \mu \mathrm{M}$ EDTA solutions. Finally, the copper-incubated samples were also assayed for enzyme activities after addition of $400 \mu \mathrm{M}$ EDTA.

All experiments were carried out in Gilford (Gilford Instrument Laboratories, Inc., Oberlin, Ohio) model 2000 or model 2400 recording spectrophotometers.

\section{RESULTS}

The following red cell enzymes were assayed for copper sensitivity: hexokinase, glucosephosphate isomerase, phosphofructokinase, aldolase, triosephosphate isomerase, glyceraldehydephosphate dehydrogenase, phosphoglyceric kinase, phosphoglyceromutase, enolase, pyruvate kinase, lactic dehydrogenase, glucose-6-phosphate dehydrogenase, 6-phosphogluconate dehydrogenase, and glutathione reductase.

Assays carried out on normal control water hemolysates without copper provided results in good agreement with those previously obtained using stabilizing solution (9). Assays performed with copper added to hemolysates demonstrated that the following enzymes were copper-sensitive: hexokinase ( $\mathrm{HK})$, phosphofruc- 
tokinase (PFK), phosphoglyceric kinase (PGK), pyruvate kinase $(\mathrm{PK})$, and 6-phosphogluconate dehydrogenase (6-PGD) (Table I).

Addition of $400 \mu_{\mathrm{M}}$ EDTA after incubation with copper restored the activities of all of the coppersensitive enzymes to normal. Table I shows that HK is most sensitive to inhibition by copper; no activity remained even after addition of the lowest concentration of copper. 6-PGD was also strongly inhibited and had no activity at a copper concentration of $100 \mu \mathrm{M}$. The activities of PFK and PK were also severely affected whereas PGK was less inhibited.

The results of enzyme assays performed after incubation of intact cells with copper are similar to those obtained through experiments in which copper was added to hemolysates (Table II). However, HK which has no activity when copper is added to the cuvette is less inhibited after incubation of red cells with copper. The effect of copper was not reversed after $18 \mathrm{hr}$ dialysis of hemolysates from incubated cells, whether dialysis was carried out against $80 \mu_{\mathrm{M} \mathrm{NaCl}}$, or $20 \mu_{\mathrm{M}}$ EDTA. The copper inhibition was relieved only when EDTA was added directly to the reaction at a final concentration of $400 \mu \mathrm{M}$.

The inhibition of the described enzymes cannot be attributed to the sulfate ion. Only G-6-PD was sensitive to sulfate in the concentration of $5 \mathrm{~mm}$.

\section{DISCUSSION}

In some patients with Wilson's disease, increases of serum copper levels are associated with a decrease of plasma ceruloplasmin levels to below normal levels. Under these circumstances most of the serum copper is not bound to ceruloplasmin, and may well be the toxic agent which leads to hemolytic anemia. In the present study, the levels of copper added to plasma are similar to those encountered in Wilson's disease, but well below the concentrations which have been used by other

TABLE I

Copper-Induced Inhibition of $H K, P F K, P G K, P K$,

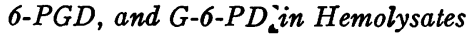

\begin{tabular}{|c|c|c|c|c|c|c|c|}
\hline \multirow[b]{2}{*}{ Enzyme } & \multirow[b]{2}{*}{$\begin{array}{c}\text { Activity } \\
\text { without } \\
\mathrm{Cu}^{++}\end{array}$} & \multicolumn{6}{|c|}{ Activity with $\mathrm{Cu}^{++}$} \\
\hline & & $15 \mu \mathrm{M}$ & $\begin{array}{l}\text { In- } \\
\text { hibi- } \\
\text { tion }\end{array}$ & $50 \mu \mathrm{M}$ & $\begin{array}{l}\text { In- } \\
\text { hibi- } \\
\text { tion }\end{array}$ & $100 \mu \mathrm{M}$ & $\begin{array}{l}\text { In- } \\
\text { hibi- } \\
\text { tion }\end{array}$ \\
\hline & & & $\%$ & & $\%$ & & $\%$ \\
\hline HK & 0.52 & $\mathbf{0}$ & 100 & 0 & 100 & $\mathbf{0}$ & 100 \\
\hline PFK & 9.51 & 5.46 & 43 & 1.42 & 85 & 0.05 & 99 \\
\hline PGK & 64.2 & 54.6 & 17 & 30.9 & 62 & 31.0 & 62 \\
\hline PK & 4.27 & 0.95 & 77 & 0.52 & 87 & 0.49 & 88 \\
\hline 6-PGD & 5.63 & 1.53 & 73 & 1.02 & 82 & 0 & 100 \\
\hline G-6-PD & 9.72 & 10.7 & 0 & 7.67 & 21 & 6.80 & 30 \\
\hline
\end{tabular}

Values expressed as international units per gram hemoglobin (9).
TABLE II

Inhibition of $H K, P F K, P G K, P K$, and 6-PGD after Incubation of Intact Cells with Copper

\begin{tabular}{lccccccc}
\hline & & \multicolumn{6}{c}{ Assays with Cu++ } \\
\cline { 3 - 8 } Enzyme & $\begin{array}{c}\text { Assays } \\
\text { without } \\
\text { Cu++ }\end{array}$ & $15 \mu \mathrm{M}$ & $\begin{array}{c}\text { In- } \\
\text { hibi- } \\
\text { tion }\end{array}$ & $50 \mu \mathrm{M}$ & $\begin{array}{c}\text { In- } \\
\text { hibi- } \\
\text { tion }\end{array}$ & $100 \mu \mathrm{M}$ & $\begin{array}{c}\text { In- } \\
\text { hibi- } \\
\text { tion }\end{array}$ \\
\hline & & & $\%$ & & $\%$ & & $\%$ \\
HK & 0.61 & 0.19 & 68 & 0.02 & 96 & 0 & 100 \\
PFK & 9.50 & 5.32 & 44 & 1.29 & 86 & 0.031 & 99 \\
PGK & 68.0 & 55.2 & 18 & 28.7 & 57 & 28.3 & 58 \\
PK & 5.01 & 1.02 & 79 & 0.49 & 90 & 0.38 & 92 \\
6-PGD & 5.57 & 1.50 & 73 & 0.98 & 82 & 0 & 100 \\
\hline
\end{tabular}

Values expressed as international units per gram hemoglobin (9).

investigators to demonstrate inhibition of G-6-PD in lowering of red cell GSH levels (3-7). At the more nearly physiologic levels of copper which we have investigated, we did not find more than $30 \%$ inhibition of G-6-PD. Thus, it is unlikely that it is the effect of copper on this enzyme which is responsible for the hemolytic anemia which occurs in Wilson's disease. It should be pointed out, furthermore, that the use of a 6-PGD-linked assay system for G-6-PD estimations leads to exaggerated impression of the degree of inhibition of G-6-PD, since 6-PGD is much more sensitive to copper inhibition than is G-6-PD.

It seems quite possible that inhibition of other red cell enzymes by copper may be of real physiologic significance in limiting the metabolic capacity of the red cell. In this regard, the great sensitivity of hexokinase to inhibition by copper may be of considerable significance. Already one of the rate-limiting enzymes in glycolysis, inhibition of HK would result in severe impairment of red cell function and might well cause in vivo hemolysis. It is quite conceivable that so-called acquired enzymatic defects of the red cell (10-12) may be due to inhibition of erythrocyte enzymes by the elevated serum copper levels which are often found in patients with various chronic disorders.

The inhibition of glycolytic enzymes by $\mathrm{Cu}^{++}$is completely reversible by high concentrations of the chelating agent, EDTA. It is not readily reversed by washing the erythrocytes with saline or even by extensive dialysis.

This provides us with an opportunity to evaluate the minimum extent to which copper may be inhibiting red cell enzymes in vivo.

\section{ACKNOWLEDGMENTS}

This work was supported by the following grants: World Health Organization, CIRC/T 640, Deutsche Forschungsgemeinschaft BL-117-1, and HE 07449, National Institutes of Health. 


\section{REFERENCES}

1. Brinton, D. 1947. Wilson's disease. Proc. Roy. Soc. Med. 40: 556 .

2. McIntyre, N., H. M. Clink, A. J. Levi, J. N. Cumings, and S. Sherlock. 1967. Hemolytic anemia in Wilson's disease. N. Engl. J. Med. 276: 439.

3. Fairbanks, V. F. 1967. Copper sulfate-induced hemolytic anemia. Arch. Intern. Med. 120: 428.

4. Metz, E. N. 1969. Mechanism of hemolysis by excess copper. Clin. Res. 17: 32

5. Deiss, A., G. R. Lee, and G. E. Cartwright. 1970. Hemolytic anemia in Wilson's disease. Ann. Intern. Med. 73: 413.

6. Passwell, J., B. Cohen, I. Ben Bassat, B. Ramot, M. Shchory, and U. Lavi. 1970. Hemolysis in Wilson's disease. Israel J. Med. Sci. 6: 549.
7. Metz, E. N., and A. L. Sagone. 1971. Effect of copper on the hexose monophosphate shunt (HMPS) in intact RBC. Clin. Res. 19: 426.

8. Willms, B., K. G. Blume, and G. W. Löhr. 1972. Hämolytische Anämie bei Morbus Wilson. Klin. Wochenschr. In press.

9. Beutler, E. 1971. Red Cell Metabolism: A Manual of Biochemical Methods. Grune \& Stratton, Inc., New York.

10. Boivin, P. 1970. Enzymopathies erythrocytaires secondaires et acquises. Presse Med. 78: 157.

11. Schröter, W. 1970. Chronische idiopathische infantile Pancytopenie. Schweiz. Med. Wochenschr. 100: 1101.

12. Kleeberg, U. R., H. Heimpel, E. Kleihauer, and A. Olischläger. 1971. Relativer Glutathion-und/oder Pyruvatkinasemangel in den Erythrozyten bei Panmyelopathien und akuten Leukämien. Klin. Wochenschr. 49: 557. 